\title{
Review of Entrepreneurship Education Literature in Educational Contexts: Bibliometric Analysis
}

\author{
İsa Deveci* \\ Department of Science Teaching, Kahramanmaras Sutcu Imam University, Faculty of \\ Education, Kahramanmaras \\ ORCID: 0000-0003-0191-1212
}

\begin{tabular}{|c|c|}
\hline Article history & The purpose of this paper is to investigate the descriptive and evaluati \\
\hline $\begin{array}{l}\text { Received: } \\
15.03 .2021\end{array}$ & $\begin{array}{l}\text { findings of articles conducted in educational contexts on entrepreneurship } \\
\text { education in the Web of Science (WoS) database. For this purpose, the }\end{array}$ \\
\hline $\begin{array}{l}\text { Received in revised form: } \\
10.06 .2021\end{array}$ & $\begin{array}{l}\text { bibliometric analysis method was used in this study. This systematic } \\
\text { literature review examined } 352 \text { scientific articles published from } 1991 \text { to } \\
2020 \text { in the WoS database. VOSviewer software was used to visualize the }\end{array}$ \\
\hline $\begin{array}{l}\text { Accepted: } \\
21.06 .2021\end{array}$ & $\begin{array}{l}\text { results of the analysis. The descriptive results showed that the most } \\
\text { articles, in terms of years, were published in 2017; Matlay was the most }\end{array}$ \\
\hline Key words: & productive author, and Lappeenranta University of Technology was the \\
\hline $\begin{array}{l}\text { Entrepreneurship education, } \\
\text { Enterprise education, } \\
\text { Entrepreneurial education, } \\
\text { Bibliometric analysis, } \\
\text { Web of science }\end{array}$ & $\begin{array}{l}\text { most productive organization; Education }+ \text { Training was the most } \\
\text { productive journal and England was the most productive country. The } \\
\text { evaluative results showed that Matlay had the largest co-authorship } \\
\text { network; England was the country with the highest co-authorship network } \\
\text { and the University of Tasmania and Birmingham City University had the } \\
\text { largest co-authorship network. Moreover, Matlay had the highest } \\
\text { (citations and total link strength) co-citations of cited authors. On the } \\
\text { other hand, Kuratko had the highest (citations and total link strength) co- } \\
\text { citations of cited references. Finally, the keywords occurrence networks } \\
\text { showed that the biggest node was entrepreneurship education. Based on } \\
\text { these results, systematic literature reviews on entrepreneurship education } \\
\text { in educational contexts at the national level in different countries could be } \\
\text { carried out. }\end{array}$ \\
\hline
\end{tabular}

\section{Introduction}

Studies on entrepreneurship education in educational contexts are increasing every year (Deveci \& Seikkula-Leino, 2018). In this sense, Haara et al. (2016) point out that pedagogical entrepreneurship is a relatively new area of interest in schools, as well as in teaching and learning research. Moreover, entrepreneurship education is seen as a tool to solve today's problems such as high youth unemployment, lack of entrepreneurial mindset and skills (Sommarström et al., 2020). Furthermore, Author (Deveci \& Seikkula-Leino, 2018) states that the concepts of entrepreneurship and entrepreneurship education are now appearing in educational curriculums in many countries.

\footnotetext{
* Correspondency: deveciisa@gmail.com
} 
Entrepreneurial education is defined as a whole education and training activity (whether it is an education system or a non-educational system) that tries to develop participants' entrepreneurial intention or some factors that affect the intention such as entrepreneurial knowledge, desirability of the entrepreneurial activity or its feasibility (Afriyie \& Boohene, 2014; Liñán, 2004). Maina (2013) states that entrepreneurial education is a part of the education system that includes the skills acquisition, management skills and ideas that people need to realize their intentions. According to Rantanen and Toikko (2013), entrepreneurial education is seen as a learning that supports an active and self-initiated way of functioning, which provides students with the opportunity to develop their own skills. Thus, the term 'entrepreneurial education' covers both entrepreneurship and enterprise concepts [The Quality Assurance Agency (QAA), 2018]. In this sense, it can be said that entrepreneurial education is an understanding of education that includes entrepreneurship education and enterprise education. Although there are differences between entrepreneurship and entrepreneurship education, there is an important overlap between the way they are designed and presented (Preedy, Jones, Maas, \& Duckett, 2020). In this sense, enterprise education is defined as the process of increasing students' capacity to generate ideas and developing the behaviors, attributes and competencies required to achieve this (QAA, 2018). On the other hand, entrepreneurship education equips students with the additional knowledge, attributes and capabilities needed to give students the opportunity to apply these skills in the context of starting a new venture or business (QAA, 2012). As a result, in this bibliometric research, keywords consisting of "entrepreneurial education," "entrepreneurship education," and "enterprise education," were used to capture the articles on entrepreneurship education in educational contexts.

The number of researchers approaching entrepreneurship education from an educational perspective is increasing (Brentnall, 2020; Clarke et al., 2020; Elo \& Kurtén, 2020). Fellnhofer (2019) argues that there is a lot of retrospective research literature on entrepreneurship education, which makes it difficult to provide a general perspective. Fellnhofer (2019) also points out that this difficulty can be overcome with bibliometric analysis. In respect to this, the increase in the number of studies on entrepreneurship education in educational context reveals the need for bibliometric research on this subject. Thus, this study aims to examine descriptive and evaluative findings based on articles conducted in educational contexts on entrepreneurship education in the Web of Science (WoS) database. In accordance with this purpose, this research is believed to make three important contributions to the literature. Firstly, this research will present an overview of the international development of entrepreneurship education in educational contexts in the WoS database. Secondly, the collaboration of entrepreneurship education researchers in educational contexts in the WoS database will be revealed. Thirdly, the citation analysis findings and keyword findings will identify the most cited articles and reveal frequently used keywords. In fact, all these contributions will give a general perspective to new researchers working in this field. In this way, entrepreneurship education researchers who focus especially on educational contexts will be able to see the authors, articles, organizations, institutions, journals, references, keywords and alike, that stand out. As a result, the sub-problems of this research are as follows:

(1) What is the distribution of descriptive results (years, authors, institutions, countries and journals) of articles published on entrepreneurship education in educational contexts in the WoS database? 
(2) What is the distribution of evaluative results (co-authorship network, co-citations, cooccurrence keywords) of articles published on entrepreneurship education in educational contexts in the WoS database?

\section{Literature review}

There is an increase in the number of studies aimed at revealing the general trends of entrepreneurship education in the literature because entrepreneurship education has been an accepted part of education that has been studied for many years. Thus, it is possible to see many bibliometric studies on entrepreneurship in the literature. Several studies have been carried out in business and economic contexts (Servantie et al., 2016; Uribe-Toril et al., 2019). For example, Servantie et al. (2016) examined the main characteristics of the studies (contributors, keywords and concepts, places of production, journals), main references and clusters of references on entrepreneurship education (management, business, marketing). Additionally, Uribe-Toril et al. (2019) conducted bibliometric analysis on the relationship between corruption and entrepreneurship. Moreover, Indarti et al. (2020) examined the trends of studies (from 1988 to 2018) on ethnic entrepreneurship, in the context of growing markets, in terms of definitions, theories, themes, methodologies and settings. Here, it is worth noting that these studies have been carried out in the contexts of business and economics.

It is also possible to see bibliometric analysis studies conducted on entrepreneurship education from general perspectives (Aparicio et al., 2019; Dolhey, 2019; Fellnhofer, 2019; Rey-Martí et al., 2016). For example, Aparicio et al. (2019) selected WoS sub-categories (business, management, economics, education educational research, and other disciplines); thus, drawing attention to both educational contexts and other disciplines in their systematic review of entrepreneurship education. Remarkably, Aparicio et al. (2019) stated that, as a result of their research, entrepreneurship education research has evolved from entrepreneurship education as part of an economic development strategy to entrepreneurship education from an academic perspective. Fellnhofer (2019) aimed to provide an overview of clusters in the entrepreneurship education literature in order to contribute to the future entrepreneurship education research literature (WoS categories: education and educational research, public administration, geography and sociology categories). In fact, Fellnhofer (2019) pointed out that entrepreneurship education has a significant volume in the educational context. Dolhey (2019) performed a bibliometric analysis of research on entrepreneurial intentions from the year 2000 to 2018 in the Scopus database. Moreover, Rey-Martí et al. (2016) conducted bibliometric analysis on social entrepreneurship. Additionally, Sassetti et al. (2018) presented an open, systematic and bibliometric review of entrepreneurial cognition as a field of study from a more dynamic perspective, based on Socially Situated Cognition theory. Furthermore, Schmitz et al. (2017) examined the scientific literature on innovation and entrepreneurship to explain how the field is organized; thus, guiding future research, main terms and definitions, theoretical frameworks, and empirical models. As a result, it can be seen that these studies focus on general entrepreneurship education rather than focusing on entrepreneurship education in the educational context.

In the literature, there are also bibliometric studies carried out on entrepreneurship education from a pedagogical perspective (Gabrielsson et al., 2020; Kakouris \& Georgiadis, 2016; Zheng, 2018). For example, the bibliometric analysis performed by Kakouris and Georgiadis (2016) revealed how entrepreneurship education and entrepreneurial learning have been introduced, addressed and discussed in the extant literature during the last decades (Scopus database). Kakouris and Georgiadis (2016) used keywords such as "entrepreneurship", 
"innovation," "education," and "learning". However, the current research is quite different from the research conducted by Kakouris and Georgiadis (2016) because it takes into account the WoS database and uses different keywords (entrepreneurial, entrepreneurship and enterprise in educational contexts).

Gabrielsson et al. (2020) examined knowledge accumulation in research on pedagogy in entrepreneurship education using business source complete (BSC), Education Resources Information Centre (ERIC) and Scopus databases. The current research is also quite different from that of Gabrielsson et al. (2020), because the current research takes into account the WoS database, and chose "Education Educational Research" as a category. Zheng (2018) conducted bibliometric analysis on entrepreneurship education in China. As a result, it can be said that there is no bibliometric analysis investigating studies conducted in educational contexts on entrepreneurship education (entrepreneurial, entrepreneurship and enterprise in educational context) in the WoS database.

\section{Method}

The bibliometric method is preferred for investigating the latest research status and trends on a particular topic, including the number of articles, geography, journal and topic distributions, productive authors and institutions, academic collation and article citations ( $\mathrm{Yu}$ et al., 2016). In this sense, Broadus (1987) defines the physical numbers of publications, their bibliographic citations and their logical measurement as bibliometrics. Also, Pritchard (1969) states that the term 'bibliometrics' will be used explicitly in all studies which seek to quantify the processes of written communication and will be rapidly accepted in the field of information science. Thus, bibliometric methods have been used to provide quantitative analysis of written publications or academic literature in recent years (Bellis, 2009; Ellegaard \& Wallin, 2015). Bibliometric indicators can also be distinguished as descriptive bibliometry and evaluative bibliometry during the analysis process (Van-Leeuwen, 2004). In this sense, the WoS database provides data on output, dissemination, collaboration and impact; thus, it is possible to conduct bibliometric analysis by using data on scientific research outputs (DeBakker et al., 2005). The current research used bibliometric analysis. In order to examine content of articles both what the WoS database and the VOSviewer software offer were utilized. The VOSviewer software was developed by Van-Eck and Waltman (2010) and it is a text mining software used to visualize similarities between different objects. Examples of such objects include countries, keywords, journals, authors and other bibliometric information extracted from scholarly databases (Wong et al., 2020). Thus, in this research, VOSviewer software was used to visualize the descriptive and evaluative results.

In the first step, the systematic literature search, the WoS database was taken into consideration. Thus, by preventing biases of journals at a very local level, international journals were reached. In addition, the systematic literature review was conducted using the WoS Core Collection database. During the literature review process, keywords were searched in "title". The reason for searching in the title is that the review desired to directly access articles specific to entrepreneurship education. For example, if the summary, keywords or any part of the full text is searched, articles in many different areas were reached outside of the educational context. The keywords searched in the title consisted of the expressions, "enterprise education," "entrepreneurial education," and "entrepreneurship education". These expressions were preferred because these concepts are generally used in research on entrepreneurship education. For example, the expressions, "entrepreneurship education," and "enterprise education," are used interchangeably, and, "entrepreneurial education," includes both of them (Gibb, 2002; Hannon, 2018; Rodriguez \& Lieber, 2020; Quality Assurance 
Agency, 2018). There was also no year limit during the literature review process for accessing articles. In the first step, a total of 1829 documents were obtained. Subsequent processes, following inclusion and exclusion criteria, are presented in Table 1.

Table 1. Systematic review steps regarding inclusion and exclusion criteria

\begin{tabular}{|c|c|c|}
\hline Criteria & & Information \\
\hline \multirow{6}{*}{ First step } & Data base & WoS (Web of Science Core Collection) \\
\hline & Indexes & All of it \\
\hline & Date & 31.10 .2020 \\
\hline & Years & All \\
\hline & Searched for & $\begin{array}{l}\text { In Title ( } \mathrm{TI}=\text { ("entrepreneurship education" or "enterprise } \\
\text { education" or "entrepreneurial education")) }\end{array}$ \\
\hline & Results & 1829 Documents \\
\hline \multicolumn{3}{|c|}{ Refine STEPS } \\
\hline Second step & Language & 1756 Documents (English) \\
\hline Third step & Document types & 875 (articles) \\
\hline Fourth step & Indexes & 738 (articles) (SCI-expanded, SSCI, A\&HCI, ESCI) \\
\hline Fifth step & WoS category & 352 (articles) (Education and Educational Research) \\
\hline
\end{tabular}

In the second step, since the indexes with international characteristics were taken into consideration, the documents written in the English Language were selected. Thus, the number of the documents decreased to 1756.

In the third step, the most common and popular document type, i.e., the, "article," was selected because articles provide more objective data as the most common and popular document type. With the third step, the number of articles decreased to 875 .

In the fourth step, SCI, SCI-Expanded, SSCI, A\&HCI and ESCI indexes were taken into consideration because full-text articles in scientific journals are generally included in these indexes. Moreover, in the systematic literature process, due to the research aim of focusing on article citations, article authors and scientific journals, "Conference Proceedings Citation Indexes" and "Book Citation Indexes," indices were excluded. With the selection of the index, the number of articles decreased to 738 .

In the fifth step, "Education Educational Research" was chosen as the WoS category in order to capture articles on entrepreneurship education especially in educational contexts. After all these inclusion and exclusion criteria steps, a total of 352 articles were obtained.

\section{Data analysis}

The results of this study were presented under two main categories. Descriptive results were given under the first category of research results. Thus, in the first category, the descriptive results reflected the frequency values for the numbers of the published articles by years, authors, institutions/organizations, journals and countries/regions. In this sense, both the WoS database and VOSviewer software were used to reveal descriptive results. the second category were the evaluative results. Thus, the evaluative results of 352 articles were analyzed and visualized using the VOSviewer software. The analysis type, analysis unit and counting method considered in VOSviewer software are shown in Table 2. 
Table 2. The analysis types of evaluative results

\begin{tabular}{|c|c|c|}
\hline Type of analysis & Unit of analysis & Counting Method \\
\hline \multirow{3}{*}{ Co-authorship } & Authors & Full counting \\
\hline & Countries & Full counting \\
\hline & Organizations & Full counting \\
\hline \multirow{2}{*}{ Co-citations } & Cited authors & Full counting \\
\hline & Cited references & Full counting \\
\hline Co-occurrence & Author keywords & Full counting \\
\hline
\end{tabular}

Peters and Van-Raan (1991) state that co-authorship analysis reveals the authorship pattern and the link between collaborating authors. Thus, it is possible to examine cooperation models and link collaborating authors, countries and institutions as analysis units. Moreover, co-citation refers to the frequency/occurrence at which two articles are cited together in another document (Small, 1973; Wang, Liang, Jia, Ge, Xu, \& Wang, 2016). In this sense, it is possible to analyze co-citations according to both the "cited authors," and the "cited references," units.

The number of occurrences of an author keyword is defined as the frequency of a keyword while the frequency of co-occurrence is defined as the frequency of a keyword pair that occurs concurrently (Zhang, Yu, Zheng, Long, Lu, \& Duan, 2016). Thus, it is possible to determine the hot spots in the research field by using the keyword "co-occurrence" (Zhang et al., 2016). Also, the "full counting" method, shown in Table 2, means giving a score to each author with a full weight of one (Perianes-Rodriguez, Waltman \& Van-Eck, 2016). PerianesRodriguez et al. (2016) state that although it has some limitations, the "whole count," method is generally used. Thus, the "full counting" method was used in the current research.

\section{Validity and reliability of the research}

In order to ensure validity in the study, the WoS database, which is one of the most reputable databases (Doulani, 2020), was taken into consideration. The systematic literature review process is explained in detail to ensure the reliability of the research. For example, the exclusion and inclusion criteria were based on the options given in the WoS database. Thus, the researcher did not use criteria for inclusion or exclusion, depending on his personal decisions, out of the possibilities of the WoS database.

\section{Results}

In this section, descriptive and evaluative findings of 352 articles obtained as a result of the systematic literature review are given.

\section{Descriptive results on years, authors, institutions, journals and countries}

In this section, the descriptive results regarding the years, authors, institutions, journals and countries categories are given. Figure 1 shows the total number of articles by years. 


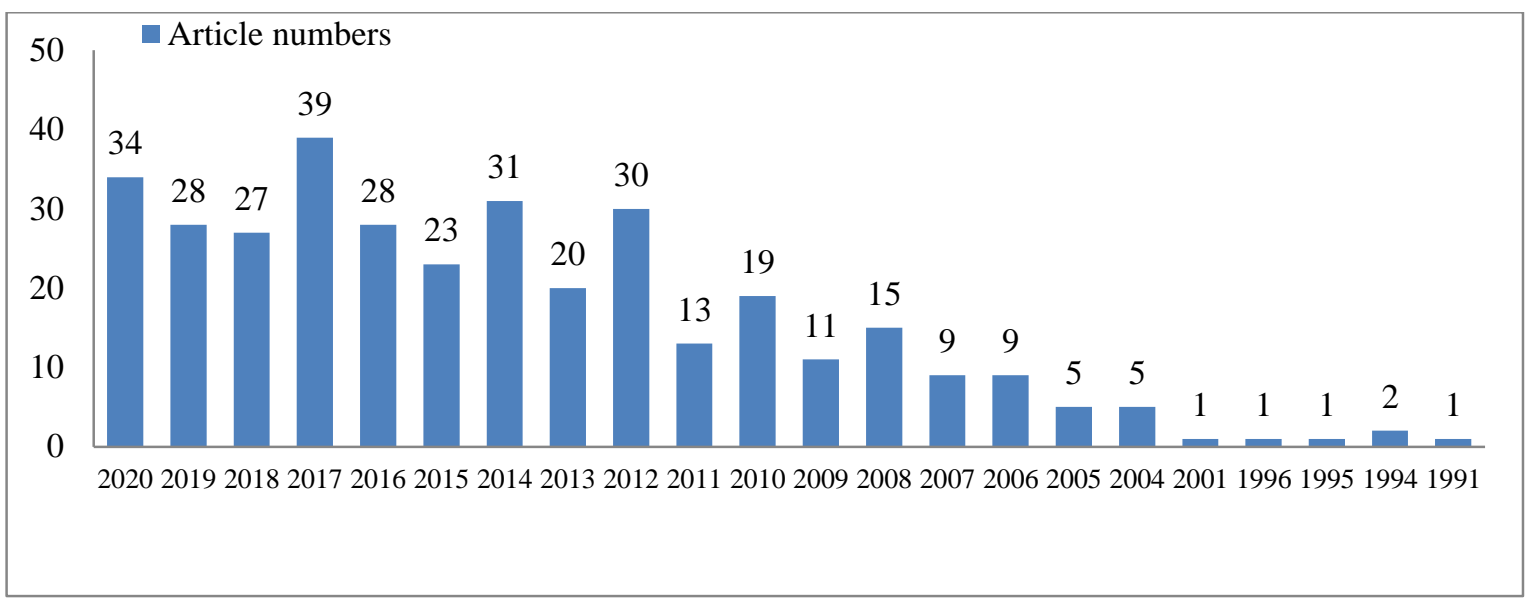

Figure 1. Number of articles per year.

There was no filtering by year in the WoS database, so a total of 352 articles were found. Figure 1 shows that the first entrepreneurship education article in an educational context, according to the inclusion and exclusion criteria, was published in 1991. Moreover, it was determined that five articles were published up until 2000. Furthermore, there has been an increase in the number of articles after 2000. Also, more articles were published in 2012, 2014, 2017 and 2020 than in any other years. Figure 2 lists the top 22 authors, who published the maximum number of articles on entrepreneurship education in educational contexts.

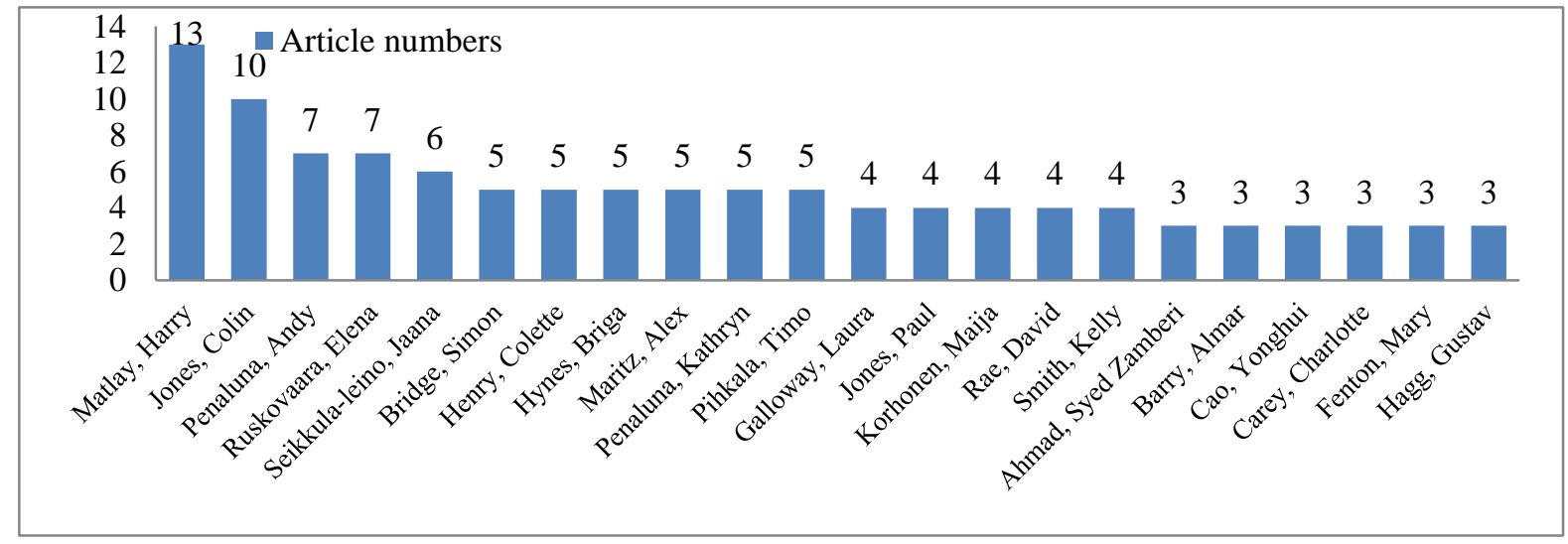

Figure 2. Number of articles per author.

Figure 2 contains only 22 of the 637 authors. The first rank was acquired by Matlay, with 13 articles in the WoS. The second rank was acquired by Jones, with 10 articles. Furthermore, each of the 551 authors published an article. Figure 3 shows the top 22 journals, which published the maximum number of articles on entrepreneurship education in educational contexts. 


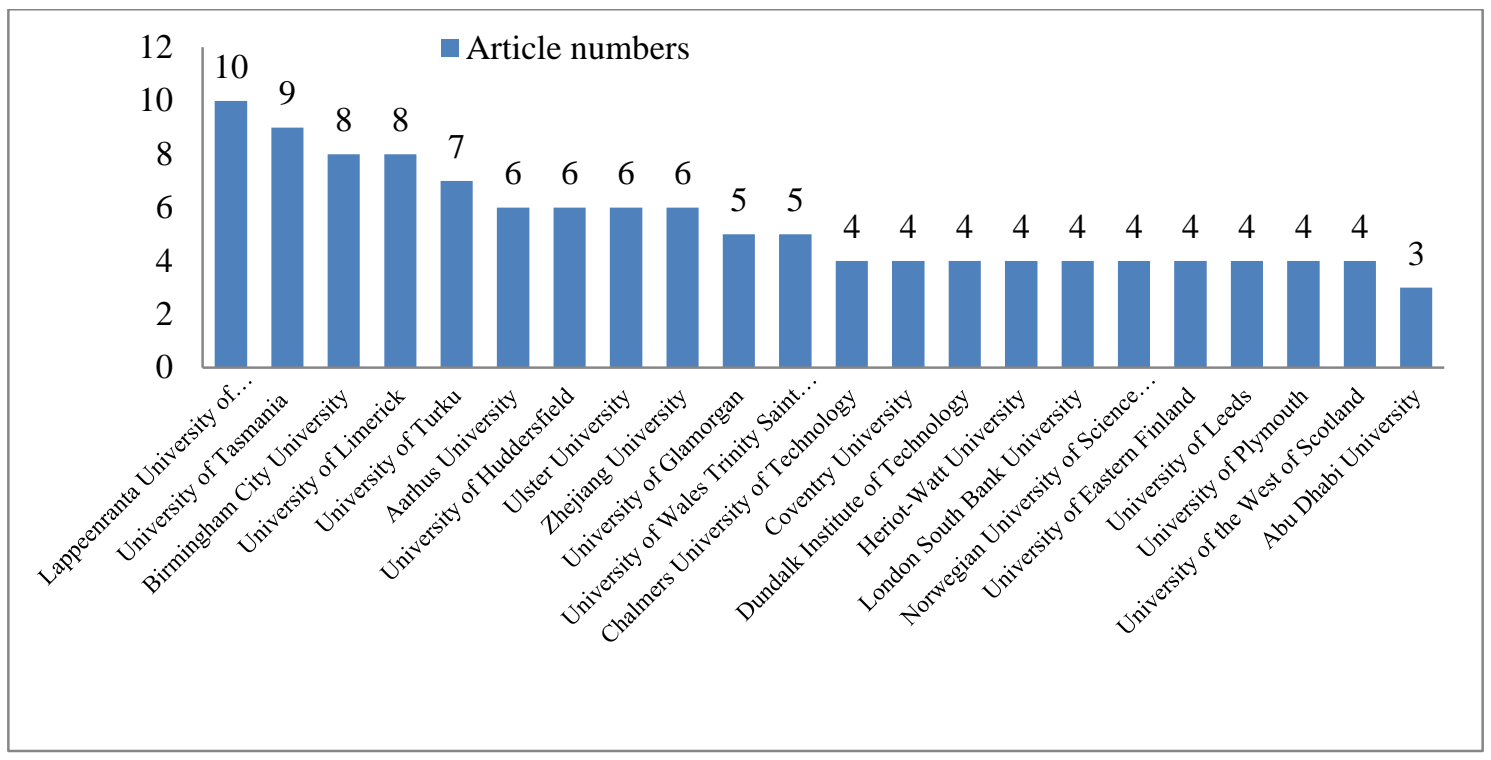

Figure 3. Number of articles per institution/organization.

Figure 3 contains only 22 of the 371 institutions. The first rank was acquired by the Lappeenranta University of Technology with ten articles in the WoS. The second rank was acquired by the University of Tasmania with nine articles. Moreover, it was determined that eight articles were published through Birmingham City University, eight articles through the University of Limerick, eight articles through the University of Turku, six articles through Aarhus University, six articles through the University of Huddersfield, six articles through Ulster University, and six articles through Zhejiang University. Figure 4 contains only 22 of the 84 journals. In this sense, it was determined that the journal named Education + Training in which 122 articles were published was a top journal. Further, 49 articles were published in the second-ranked journal, Industry and Higher Education. Moreover, it was determined that 21 articles were published in the International Journal of Management Education, eleven articles in the Academy of Management Learning Education, ten articles in Studies in Higher Education, and eight articles in Educational Sciences Theory Practice.

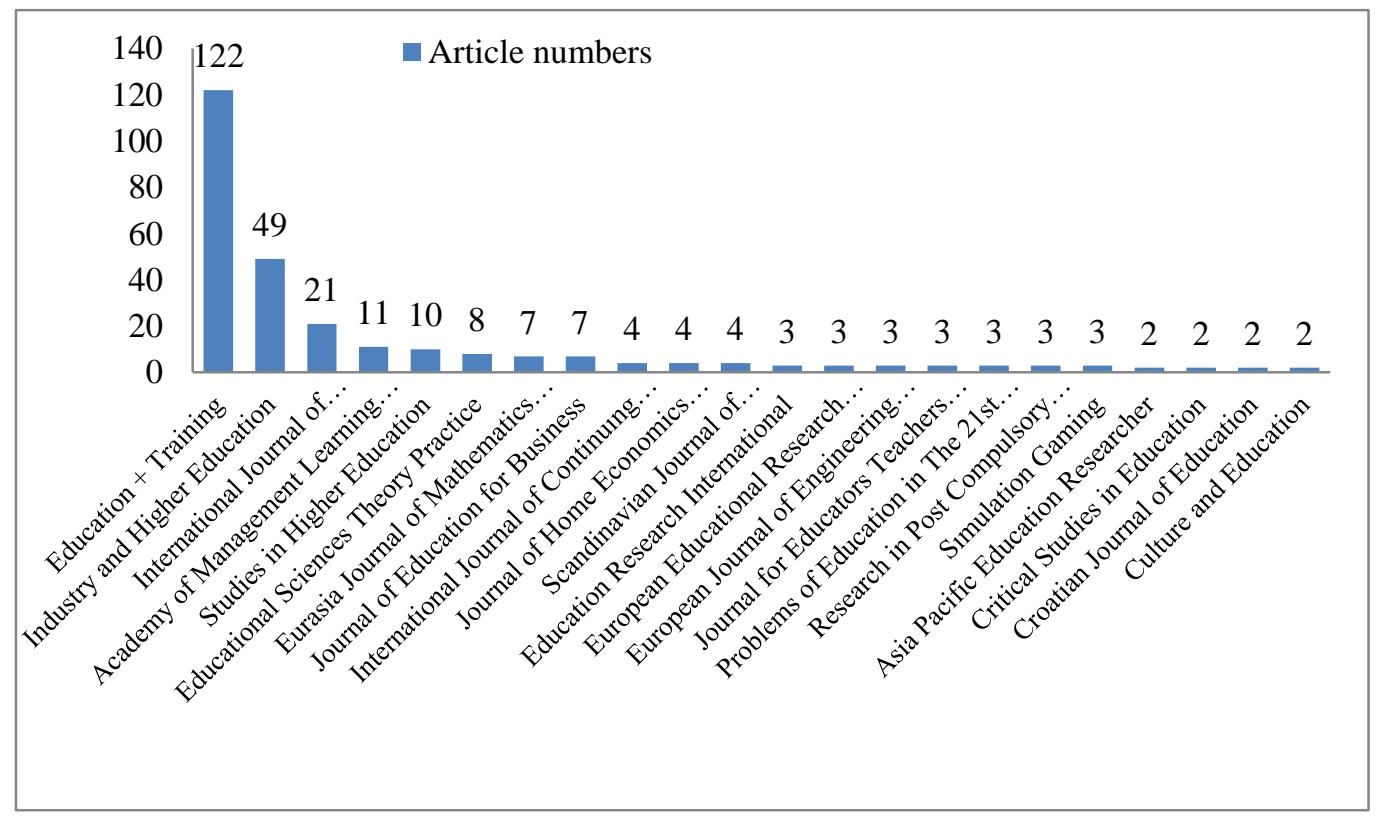

Figure 4. Number of articles per source/journal. 
Figure 5 shows the top 22 most productive countries/regions on entrepreneurship education in educational contexts. Thus, Figure 5 contains only 22 of the 66 countries. The findings show that England in which 71 articles were published, was the top country. Further, 35 articles were published in the second-ranked country, the USA. Moreover, it was determined that 29 articles were published in China, 25 articles were published in Australia, 24 articles were published in Finland, 20 were published in Wales, 15 articles were published in Ireland and Sweden, 14 articles were published in Norway, 13 articles were published in South Africa, 12 articles were published in Denmark, 11 articles were published in Scotland and Spain, 10 articles were published in North Ireland.

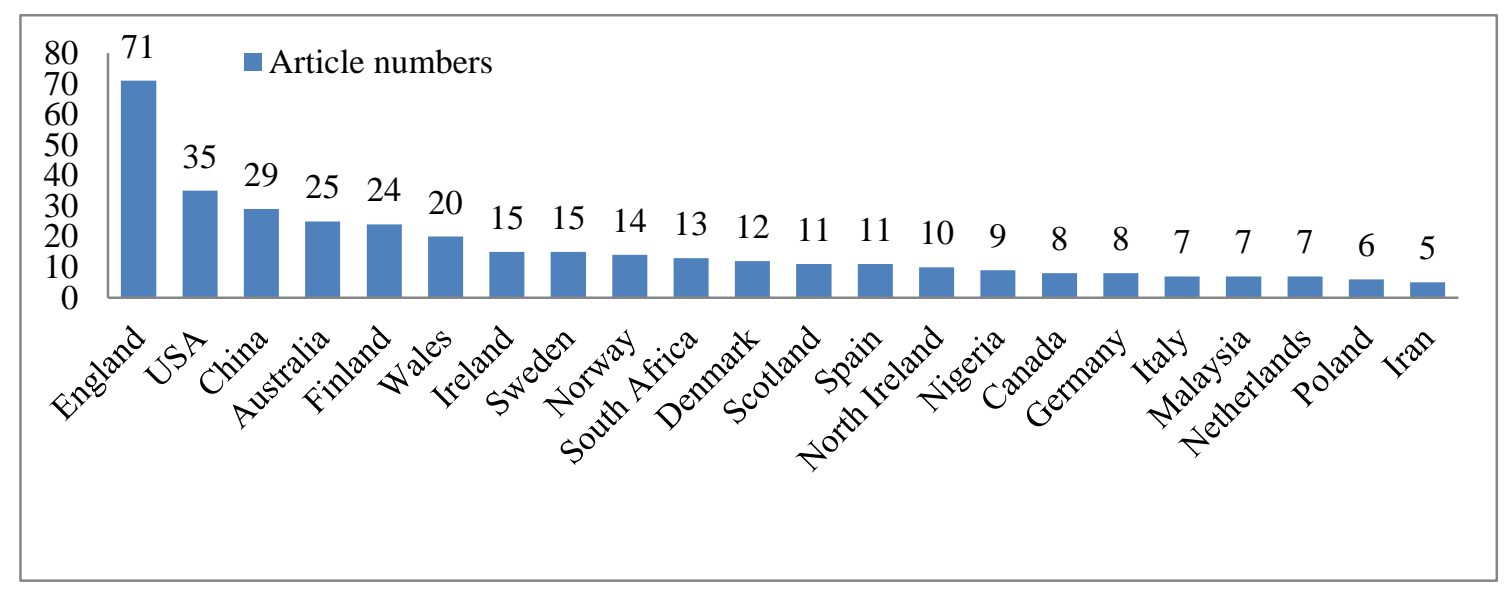

Figure 5. Number of articles for per country/region.

\section{Evaluative results on co-authorship, co-citation and co-occurrence keywords}

In this section, the evaluative results regarding co-authorship, co-citation and cooccurrence keywords categories are given. Figure 6 shows a co-authorship network visualization map for international collaborations of authors on entrepreneurship education in educational contexts.

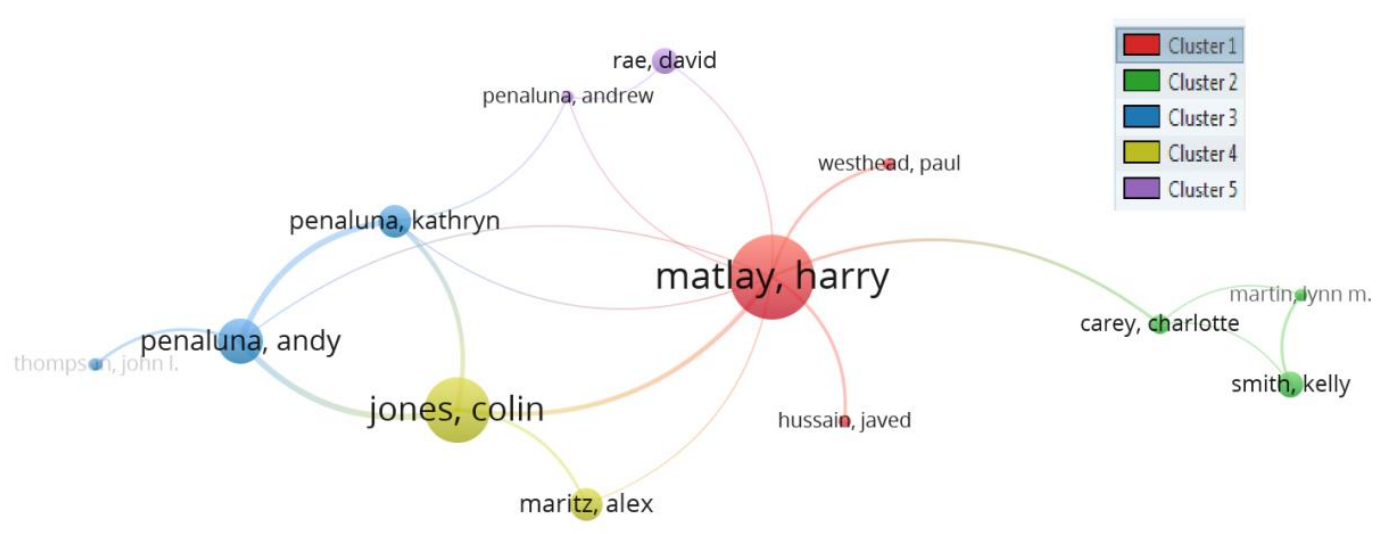

Figure 6. Co-authorship network visualization map for authors

Figure 6 shows authors' strength of collaboration on the network visualization map. The thickness of the lines indicates the strength of the collaboration; the size of the circle indicates the large number of articles; and the colors indicate the cluster of collaborations. The least number of articles per author was set as two articles; of the 637 authors, 87 authors met the 
threshold. The findings show that the collaborating authors were categorized into five. Clusters: Cluster 1 contained three items (Hussain, Matlay, and Westhead); Cluster 2 contained three items (Carey, Martin, and Smith); Cluster 3 contained three items (Penaluna A., Penaluna K., and Thompson); Cluster 4 contained two items (Jones and Maritz); and Cluster 5 contained two items (Penaluna A., and Rae). Figure 7 shows the collaboration findings of co-authorship according to countries/regions on entrepreneurship education in educational contexts.

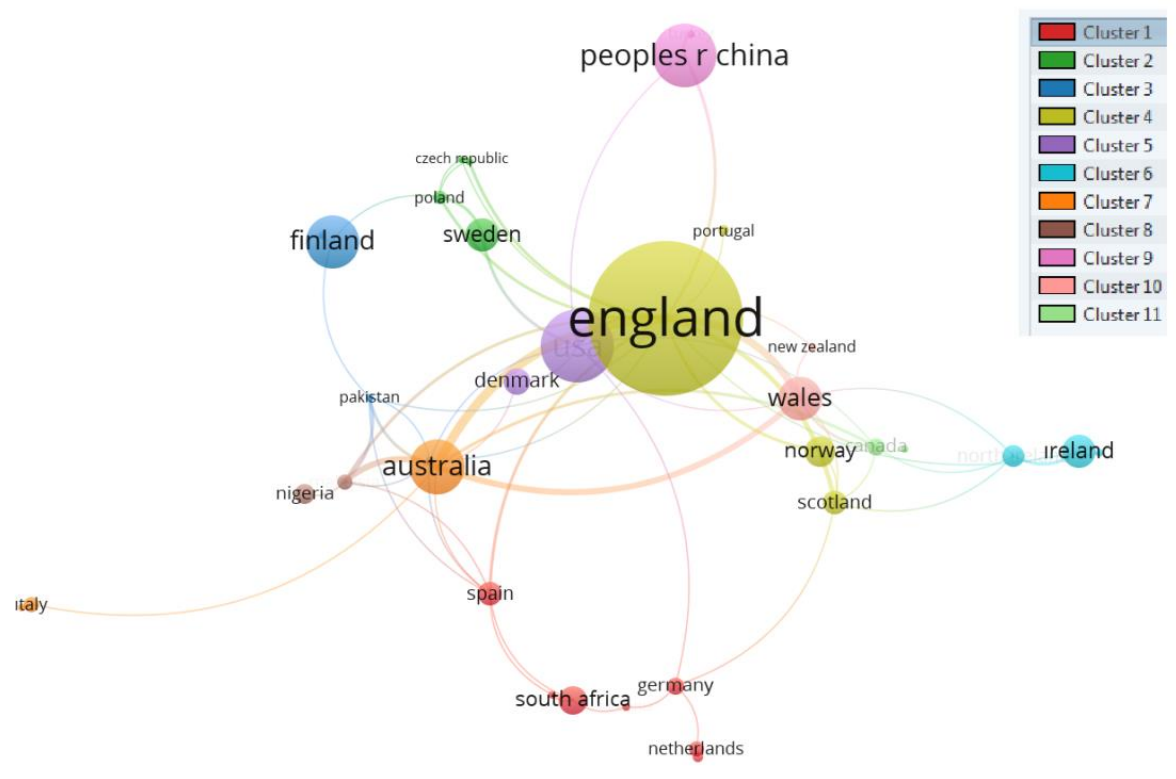

Figure 7. Co-authorship network visualization map for countries/regions

Figure 7 contains the countries/regions with the strength of collaboration on the network visualization map. The least number of articles of a country/region was set at two articles; of the 66 countries/regions, 41 countries/regions met the threshold. The findings show that the collaborating countries/regions were categorized into 11 clusters: Cluster 1 contained seven items (Germany, Iran, Netherlands, South Africa, Spain, Tanzania, Zimbabwe); Cluster 2 contained four items (Czech Republic, Hungary, Poland, Sweden); Cluster 3 contained four items (Brazil, Finland, Pakistan, United Arab Emirates); Cluster 4 contained four items (England, Norway, Portugal, Scotland), Cluster 5 contained 3 items (Croatia, Denmark, USA); Cluster 6 contained three items (Greece, Ireland, Northern Ireland); Cluster 7 contained three items (Australia, France, Italy); Cluster 8 contained two items (Malaysia and Nigeria); Cluster 9 contained two items (Peoples Republic of China, Turkey); Cluster 10 contained two items (New Zealand and Wales); and Cluster 11 contained two items (Canada and Israel). Figure 8 shows the collaboration findings of co-authorship according organizations on entrepreneurship education in educational contexts. 


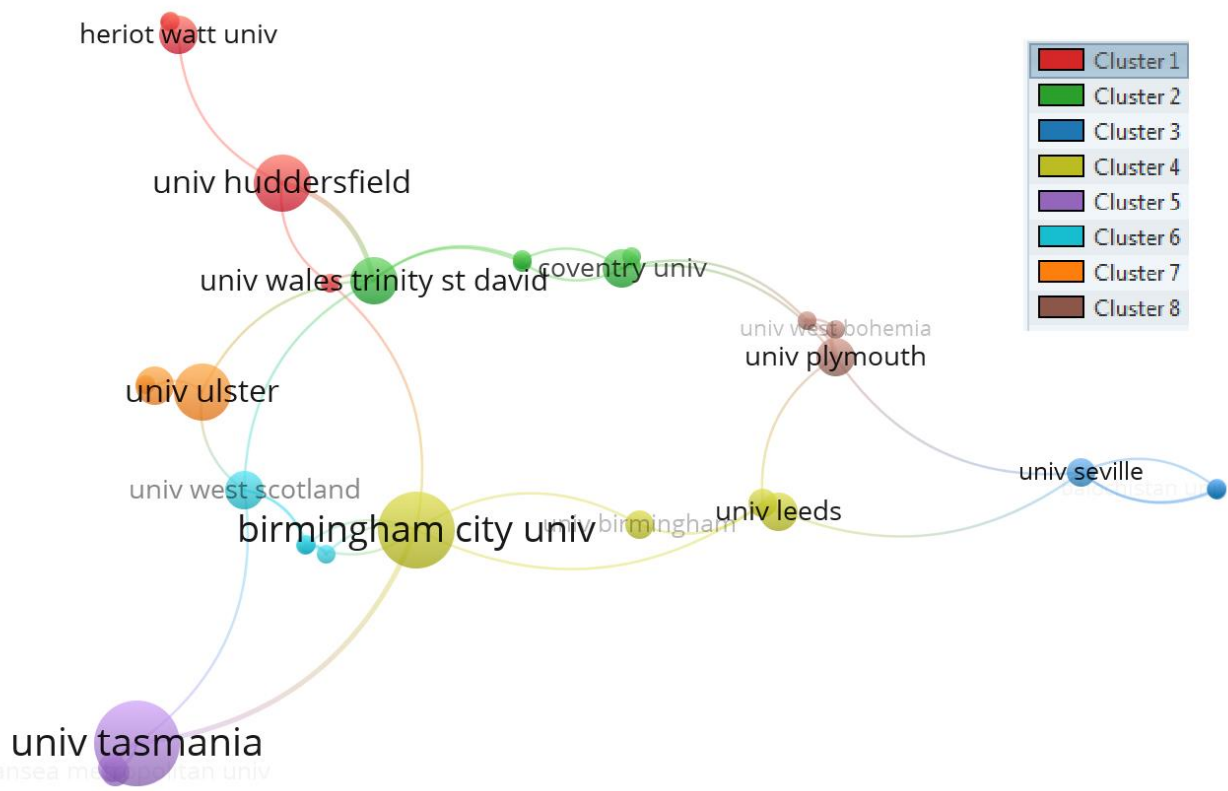

Figure 8. Co-authorship network visualization map for organizations

Figure 8 shows the organizations' strength of collaboration on the network visualization map. The least number of articles for an organization was set at two articles; of the 371 organizations, 91 organizations met the threshold. The findings show that the collaborating organizations were categorized into eight clusters: Cluster 1 contained five items (Glasgow Caledonian Univ., Heriot Watt Univ., Univ. of Huddersfield, Univ. of Strathclyde, Univ. of Teesside); Cluster 2 contained five items (Coventry Univ., Queensland Univ. of Technol, Univ. of Lincoln, Univ. of South Wales, Univ. of Wales Trinity St David); Cluster 3 contained four items (Balochistan Univ. Informant Tech, Murdoch Univ., Univ. of Malaya, Univ. of Seville); Cluster 4 contained four items (Birmingham City Univ., Manchester Metropolitan Univ., Univ. of Birmingham, Univ. of Leeds); Cluster 5 contained four items (Swansea Metropolitan Univ., Swinburne Univ. Technol., Univ. of Sheffield, Univ. of Tasmania); Cluster 6 contained four items (Univ. of Durham, Univ. of Nordland, Univ. of Oslo, Univ. of West Scotland); Cluster 7 contained three items (Dundalk Inst. Technol., Queens Univ. Belfast, Univ. of Ulster); and Cluster 8 contained three items (Univ. of Plymouth, Univ. of West Bohemia, WSB Univ. Poznan). Figure 9 shows the collaboration findings of coauthorship according to organizations on entrepreneurship education in educational contexts. 


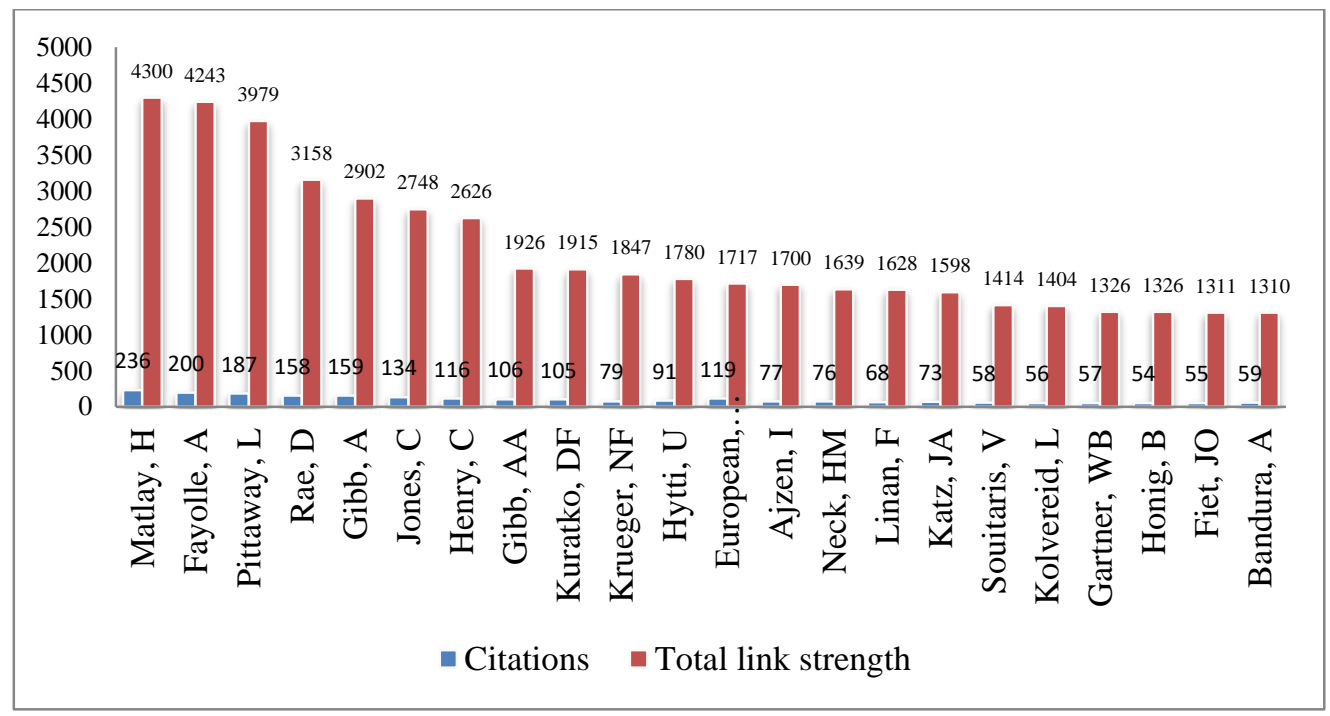

Figure 9. Co-citation of cited authors

In terms of co-citation cited authors, the least number of author citations was set as 20; of the 8387 authors, 93 authors met threshold. Thus, Figure 5 contains only 22 of the 93 authors. Co-citation refers to the incidence with which two articles are referred to simultaneously by other articles while bibliographic coupling exists (Cunill et al., 2019). Generally, the closer the two authors are, the stronger their relatedness. Based on the total link strength, Matlay is the most cited author in the WoS database, followed by Fayolle and Pittaway. Table 3 shows the co-cited references in the analyzed articles.

Table 3. Co-cited references

\begin{tabular}{|c|c|c|c|c|}
\hline $\mathbf{R}^{*}$ & Author(s) & Title & $\mathbf{C}^{* *}$ & $\begin{array}{l}\mathbf{T} \\
* * *\end{array}$ \\
\hline 1 & Kuratko, D. F. (2005). & $\begin{array}{l}\text { The emergence of entrepreneurship education: } \\
\text { Development, trends, and challenges }\end{array}$ & 76 & 667 \\
\hline 2 & $\begin{array}{l}\text { Souitaris, V., Zerbinati, S., } \\
\text { \& Al-Laham, A. (2007). }\end{array}$ & $\begin{array}{l}\text { Do entrepreneurship programmes raise entrepreneurial } \\
\text { intention of science and engineering students? }\end{array}$ & 58 & 665 \\
\hline 3 & $\begin{array}{l}\text { Fayolle, A., Gailly, B., \& } \\
\text { Lassas-Clerc, N. (2006). }\end{array}$ & $\begin{array}{l}\text { Assessing the impact of entrepreneurship education } \\
\text { programmes: a new methodology }\end{array}$ & 54 & 609 \\
\hline 4 & $\begin{array}{l}\text { Pittaway, L., \& Cope, J. } \\
\text { (2007). }\end{array}$ & $\begin{array}{l}\text { Entrepreneurship education: A systematic review of the } \\
\text { evidence }\end{array}$ & 66 & 605 \\
\hline 5 & $\begin{array}{l}\text { Peterman, N. E., \& } \\
\text { Kennedy, J. (2003). }\end{array}$ & $\begin{array}{l}\text { Enterprise education: Influencing students' perceptions } \\
\text { of entrepreneurship }\end{array}$ & 55 & 582 \\
\hline 6 & $\begin{array}{l}\text { Neck, H. M., \& Greene, P. } \\
\text { G. (2011). }\end{array}$ & $\begin{array}{l}\text { Entrepreneurship education: known worlds and new } \\
\text { frontiers }\end{array}$ & 56 & 552 \\
\hline 7 & Ajzen, I. (1991). & The theory of planned behavior & 49 & 536 \\
\hline 8 & Honig, B. (2004). & $\begin{array}{l}\text { Entrepreneurship education: Toward a model of } \\
\text { contingency-based business planning }\end{array}$ & 47 & 518 \\
\hline 9 & $\begin{array}{l}\text { Oosterbeek, H., Van- } \\
\text { Praag, M., \& Ijsselstein, A. } \\
\text { (2010). }\end{array}$ & $\begin{array}{l}\text { The impact of entrepreneurship education on } \\
\text { entrepreneurship skills and motivation }\end{array}$ & 49 & 513 \\
\hline 10. & Katz, J. A. (2003). & $\begin{array}{l}\text { The chronology and intellectual trajectory of American } \\
\text { entrepreneurship education: } 1876-1999 \text {. }\end{array}$ & 52 & 503 \\
\hline 11 & $\begin{array}{l}\text { Hytti, U., \& O’Gorman, C. } \\
(2004) \text {. }\end{array}$ & $\begin{array}{l}\text { What is "enterprise education"? An analysis of the } \\
\text { objectives and methods of enterprise education } \\
\text { programmes in four European countries }\end{array}$ & 60 & 472 \\
\hline 12 & $\begin{array}{l}\text { Fayolle, A., \& Gailly, B. } \\
(2008) .\end{array}$ & $\begin{array}{l}\text { From craft to science Teaching models and learning } \\
\text { processes in entrepreneurship education }\end{array}$ & 42 & 465 \\
\hline
\end{tabular}




\begin{tabular}{lllll}
\hline 13 & $\begin{array}{l}\text { Gorman, G., Hanlon, D., \& } \\
\text { King, W. (1997). }\end{array}$ & $\begin{array}{l}\text { Some research perspectives on entrepreneurship } \\
\text { education, enterprise education and education for small } \\
\text { business management: a ten-year literature review }\end{array}$ & 48 & 463 \\
\hline 14 & $\begin{array}{l}\text { Krueger Jr, N. F., Reilly, } \\
\text { M. D., \& Carsrud, A. L. } \\
\text { (2000). }\end{array}$ & Competing models of entrepreneurial intentions & 44 & 457 \\
\hline 15 & Mwasalwiba, E. S. (2010). & $\begin{array}{l}\text { Entrepreneurship education: a review of its objectives, } \\
\text { teaching methods, and impact indicators }\end{array}$ & 43 & 454 \\
\hline 16 & $\begin{array}{l}\text { Von-Graevenitz, } \\
\text { Harhoff, D., \& Weber, R., } \\
\text { (2010). }\end{array}$ & The effects of entrepreneurship education & 36 & 454 \\
\hline 17 & $\begin{array}{l}\text { Henry, C., Hill, F., \& } \\
\text { Leitch, C. (2005). }\end{array}$ & $\begin{array}{l}\text { Entrepreneurship education and training: can } \\
\text { entrepreneurship be taught? Part I. }\end{array}$ & 37 & 433 \\
\hline 18 & Matlay, H. (2008). & $\begin{array}{l}\text { The impact of entrepreneurship education on } \\
\text { entrepreneurial outcomes }\end{array}$ & 46 & 414 \\
\hline 19 & $\begin{array}{l}\text { Martin, B. C., McNally, J. J. } \\
\text { J., \& Kay, M. J. (2013). }\end{array}$ & $\begin{array}{l}\text { Examining the formation of human capital in } \\
\text { entrepreneurship: A meta-analysis of entrepreneurship } \\
\text { education outcomes }\end{array}$ & 36 & 401 \\
\hline 20 & $\begin{array}{l}\text { Kolvereid, L., \& Moen, Ø. } \\
\text { (1997). }\end{array}$ & $\begin{array}{l}\text { Entrepreneurship among business graduates: does a } \\
\text { major in entrepreneurship make a difference? }\end{array}$ & 26 & 359 \\
\hline 21 & $\begin{array}{l}\text { Pittaway, L., \& Cope, J. J. } \\
\text { (2007). }\end{array}$ & $\begin{array}{l}\text { Simulating entrepreneurial learning: Integrating } \\
\text { experiential and collaborative approaches to learning. }\end{array}$ & 35 & 340 \\
\hline 22 & Kirby, D. A. (2004). & $\begin{array}{l}\text { Entrepreneurship education: can business schools meet } \\
\text { the challenge? }\end{array}$ & 40 & 331 \\
\hline
\end{tabular}

*Rank; **Citations; *** Total link strength

In terms of co-citation of cited references, the least number of citations of a cited reference was set at 20 references; of 12291 references, 57 references met the threshold. Thus, Table 3 contains only 22 of the 57 references. The total link strength attribute indicates the total strength of the co-citation links of a given reference with other references. The findings show that the most co-citation of cited reference was Kuratko (2005) who has 76 citations and 667 total link strength. In this sense, Kuratko (2005) had the highest total link strength in the cocitation of cited references, followed by Souitaris et al. (2007) and Fayolle et al. (2006). Figure 10 maps the co-occurrence of keywords on entrepreneurship education in educational contexts.

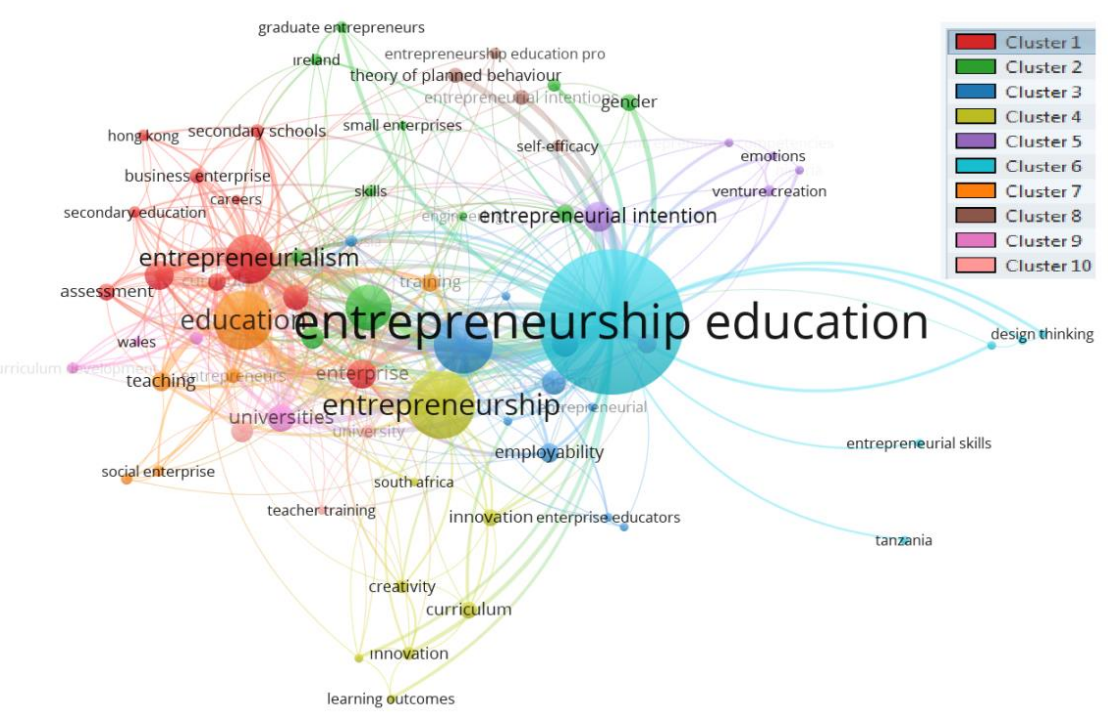

Figure 10. Network visualization map of co-occurrence of keywords 
Figure 10 shows the co-occurrence of keywords on the network visualization map. The least number of keywords was set at three keywords; of 824 keywords, 69 keywords met the threshold. The findings show that the co-occurrence keywords were categorized into 10 clusters: Cluster 1 contained 11 items (Assessment, Business Enterprise, Careers, Curricula, Enterprise, Entrepreneurialism, Hong Kong, Secondary education, Secondary schools, Students, United Kingdom); Cluster 2 contained 11 items (Engineering, Entrepreneurial selfefficacy, Experiential learning, Gender, Graduate entrepreneurs, Graduates, Higher education, Ireland, Skills, Small enterprises); Cluster 3 contained 10 items (Curriculum design, Employability, Enterprise education, Enterprise educators, Entrepreneurial, Entrepreneurial education, Entrepreneurship development, Malaysia, Networks, Pedagogy); Cluster 4 contained eight items (Creativity, Curriculum, Entrepreneurial competences, Entrepreneurship, innovation, Innovation Learning outcomes, South Africa); Cluster 5 contained six items (emotions, entrepreneurial competencies, entrepreneurial intention, entrepreneurial learning, Nigeria, venture creation); Cluster 6 contained six items (design thinking, entrepreneurial mindset, entrepreneurial skills, entrepreneurship education, experiential education, Tanzania); Cluster 7 contained six items (education, entrepreneurs, social enterprise, social entrepreneurship, teaching, training); Cluster 8 contained four items (entrepreneurial intentions, entrepreneurship education pro, self-efficacy, theory of planned behavior); Cluster 9 contained four items (curriculum development, evaluation, universities, Wales); and Cluster 10 contained three items (learning, teacher training, university).

\section{Discussion and Conclusion}

This study examined studies on entrepreneurship education in educational contexts between 1991 and 2020, based on articles in the WoS database. Although this research is not the first bibliometric study conducted on entrepreneurship education, it is the first bibliometric initiative conducted on entrepreneurship education in educational contexts in the WoS database.

When analyzed by years, it was determined that there was a significant increase in the number of articles published in educational contexts after 2000. It was also determined that the most articles were published in 2017. Gabrielsson et al. (2020) examined pedagogical studies on entrepreneurship education in different databases, and they also found similar findings. Similarly, Aparicio et al. (2019) conducted a bibliometric analysis on entrepreneurship education (business, education and other disciplines), and found that the most articles by years were published in 2017. Dolhey (2019) found that the most articles were published in 2017 in their bibliometric analysis on entrepreneurial intentions in the Scopus database. In this sense, it can be said that researchers have focused more on entrepreneurship education in terms of pedagogy, especially after 2000. In addition, the most articles were published in 2017. In terms of the number of articles per author, findings show that the most productive author is Matlay, with 13 articles; they are followed by Jones, with ten articles, and then by Penaluna A., and Ruskovaara with seven articles each.

In terms of the number of articles per journal on entrepreneurship education in educational contexts, findings indicate that the most productive journals were "Education + Training", and then "Industry and Higher Education" and "International Journal of Management Education" (WoS). In terms of productive journals, the current research findings coincide, to a certain extent, with the research findings of Gabrielsson et al. (2020). For example, Gabrielsson et al. (2020) found that the two most productive journals (in educational contexts in BSC, ERIC and Scopus) are "Education + Training" and "Industry and Higher Education". 
It can be said that a significant part of scientific discussions on pedagogy in entrepreneurship education (Gabrielsson et al., 2020) were conducted with articles published in these journals. On the other hand, Aparicio et al. (2019) found that the most productive journals are "Journal of Small Business Management," "The International Journal of Entrepreneurial Behavior \& Research," and "Journal of Business Venturing," which do not directly focus on research on the learning and education process. Differently, in the bibliometric study conducted by Dolhey (2019) on the entrepreneurial intentions, "the International Journal of Entrepreneurship and Small Business" was found to be the most productive journal. Thus, it can be said that the two most productive journals that publish educational articles on entrepreneurship education are "Education + Training" and "Industry and Higher Education". Another remarkable finding of the current research was that the two most productive institutions that publish educational articles on entrepreneurship education were "Lappeenranta University of Technology" and "the University of Tasmania".

Indarti et al. (2020) found that current studies (from 1988 to 2018) in the field of ethnic entrepreneurship in the context of growing markets were mainly conducted in developed countries and a lesser portion in developing countries, particularly Asian countries. Moreover, Dolhey (2019) found "the University of Seville" to be the most productive institution on entrepreneurship intentions. Looking at the most productive countries in terms of the countries/regions, it was determined that the three most productive countries were England, the USA and China, respectively. According to the bibliometric analysis of Dolhey (2019) on entrepreneurial intentions, the most productive country is USA. In this sense, it can be said that the USA and England are the leading countries that approach entrepreneurship education from an educational perspective.

When countries were examined in terms of co-authorship, England was the most active country on entrepreneurship education in the field of education globally, in terms of collaboration. England had strong links with Australia and Wales. Moreover, the strongest link was between Australia and England. Furthermore, findings showed that authors from England, the USA, China, Finland, Australia and Wales have co-authored the most with authors from other countries on entrepreneurship education in educational contexts. Dolhey (2019) found that the authors from the USA, Spain, the United Kingdom, Germany and Australia co-authored the most with authors from other countries on entrepreneurial intentions. When authors were examined in terms of co-authorship, Matlay was the most active author on entrepreneurship education in the field of education globally in terms of collaboration. Thus, the descriptive results of the present study showed that Matlay had the most articles on entrepreneurship education in the educational contexts. Moreover, in terms of co-authorship, Matlay had strong links with Jones, Westhead and Hussain. The strongest link was between Penaluna, A., and Penaluna K. According to Dolhey (2019), Linan is the most productive author on entrepreneurial intentions. Thus, Dolhey (2019) found that Linan has coauthored with the greatest number of authors in the data set. In fact, these results point out that the co-authorship of the authors with the most articles may also be strong. Current findings also showed that "the University of Tasmania" and "Birmingham City University" were the most active organizations on entrepreneurship education in educational contexts globally, in terms of collaboration. Thus, there was the strongest link between "the University of Tasmania" and "Birmingham City University". Moreover, "the University of Wales Trinity Saint David" had the strongest link with both "the University of Huddersfield" and "Queensland University of Technology". When authors were examined in terms of cocitation of cited authors, findings showed that Matlay is the most productive author in terms of number of articles, citations and total link strength; Fayolle followed Matlay in terms of co- 
citation. Aparicio et al. (2019) found that Katz is the most productive author according to WoS sub-categories (business, management, economics, education educational research, and other disciplines). Also, Dolhey (2019) found that the most productive author on entrepreneurial intentions is Linan. In fact, these results show that it is possible to find the most productive authors in a discipline or field that focus on entrepreneurship education from different perspectives. When references were examined in terms of co-citation of cited references, findings showed that the reference with the greatest total link strength for cocitation of cited references was Kuratko (2005); this was followed by Souitaris et al. (2007) and then Fayolle et al. (2006). Actually, it can be said that these references are based on general entrepreneurship education literature. In this sense, these findings provide information about the general entrepreneurship literature that forms the basis of the entrepreneurship education literature carried out in educational contexts. Similarly, Gabrielsson et al. (2020) found that one of the most-cited articles is Kuratko (2005); they drew attention to this issue in their research by conducting bibliometric analysis from the point of view pedagogy on entrepreneurship education in different databases. Supporting these findings, Aparicio et al. (2019) found that the most cited article belonged to Kuratko (2005). Differently, in the bibliometric research on entrepreneurial intentions conducted by Dolhey (2019), the most cited article was Krueger et al. (2000).

When keywords were examined in terms of co-occurrence networks, findings showed that the biggest node was, "entrepreneurship education". This means that the most recurring keywords were, "entrepreneurship education". Also, the two keywords with the strongest link were "education" and "entrepreneurialism". Moreover, the most linked keywords were "entrepreneurship education," "enterprise education," "entrepreneurial intention,", "pedagogy," and "entrepreneurial learning". Furthermore, the most linked keywords with the keyword, "entrepreneurship," were "entrepreneurship education," "enterprise education," "education," and "higher education". As Kakouris and Georgiadis (2016) concluded, as a result of keyword analysis, there are many educational purposes and content within the entrepreneurship literature.

On the other hand, in the research conducted by Dolhey (2019), many other keywords were found on entrepreneurial intentions in the data set, such as, "startup intention," "selfemployment intentions," "social entrepreneurial intentions," which are synonymous with, "entrepreneurial intention". In this sense, keyword co-occurrences can provide important clues to the basic keywords about the subject under review.

In this study, it may be useful to address some limitations in order to shed light on future research. First, this research was limited to 352 articles (just article documents) in the WoS database that could be accessed according to the criteria mentioned in the methods section. In this sense, other document types could be taken into consideration in future studies. In addition, only the WoS database was used to search for articles in this study. Thus, journal articles not indexed in the WoS database were not included in this study. Moreover, this systematic review only included articles published in the English language. In future research, researchers could examine the situation in national databases of their country in local languages. In this study, there was no limit to the starting point in terms of year; however the most recent studies were limited to the date 31 October 2020, when the present systematic literature review was conducted. In this sense, this year interval could be different for future studies. In this study, only the titles were searched for the keywords, "enterprise education," AND "entrepreneurial education," AND "entrepreneurship education". In future research, a systematic search could be made in other sections (for example in abstracts, in keywords and 
alike) with one of these keywords (only enterprise education). As a result, in current study, by using critical keywords in the WoS database, a comprehensive view on entrepreneurship education in educational contexts has been provided. It is thought that this study will guide researchers in terms of the basic points for future research on entrepreneurship education in educational contexts.

\section{References}

Afriyie, N., \& Boohene, R. (2014). Entrepreneurial education and entrepreneurial culture among university of cape coast students in Ghana. Athens Journal of Education, 1(4), 309-321.

Aparicio, G., Iturralde, T., \& Maseda, A. (2019). Conceptual structure and perspectives on entrepreneurship education research: A bibliometric review. European Research on Management and Business Economics, 25(3), 105-113.

Bellis, D. N. (2009), Bibliometrics and citation analysis: From the science citation index to cybermetrics. Maryland: Scarecrow Press.

Brentnall, C. (2020). Competitive enterprise education: Developing a concept. Entrepreneurship Education and Pedagogy, O(0), 1-30.

Broadus, R. N. (1987). Toward a definition of bibliometrics. Scientometrics, 12, 373-379.

Clarke, A. P., Cornes, C., \& Ferry, N. (2020). The use of self-reflection for enhanced enterprise education: A case study. Education+ Training, 62(5), 581-598.

Cunill, O. M., Salva', A. S., Gonzalez, L. O., \& Mulet-Forteza, C. (2019). Thirty-fifth anniversary of the international journal of hospitality management: A bibliometric overview. International Journal of Hospitality Management, 78, 89-101.

De-Bakker, F. G. A., Groenewegen, P., \& Den-Hond, F. A. (2005). A bibliometric analysis of 30 years of research and theory on corporate social responsibility and corporate social performance. Business \& Society, 44(3), 283-317.

Deveci, İ., \& Seikkula-Leino, J. (2018). A review of entrepreneurship education in teacher education. Malaysian Journal of Learning and Instruction, 15(1), 105-148.

Dolhey, S. (2019). A bibliometric analysis of research on entrepreneurial intentions from 2000 to 2018. Journal of Research in Marketing and Entrepreneurship, 21(2), 180199.

Doulani, A. (2020). A bibliometric analysis and science mapping of scientific publications of Alzahra University during 1986-2019. Library Hi Tech, Vol. ahead-of-print No. ahead-of-print. https://doi.org/10.1108/LHT-06-2020-0131

Ellegaard, O., \& Wallin, J. A. (2015). The bibliometric analysis of scholarly production: How great is the impact? Scientometrics, 105(3), 1809-1831.

Elo, J., \& Kurtén, B. (2020). Exploring points of contact between enterprise education and open-ended investigations in science education. Education Inquiry, 11(1), 18-35.

Fayolle, A., Gailly, B., \& Lassas-Clerc, N. (2006). Assessing the impact of entrepreneurship education programmes: a new methodology. Journal of European Industrial Training, 30(9), 701-720.

Fellnhofer, K. (2019). Toward a taxonomy of entrepreneurship education research literature: A bibliometric mapping and visualization. Educational Research Review, 27, 28-55.

Gabrielsson, J., Hägg, G., Landström, H., \& Politis, D. (2020). Connecting the past with the present: the development of research on pedagogy in entrepreneurial education. Education + Training, 62(9), 1061-1086.

Gibb, A. (2002). In pursuit of a new 'enterprise' and 'entrepreneurship' paradigm for learning: creative destruction, new values, new ways of doing things and new 
combinations of knowledge. International Journal of Management Reviews, 4(3), 233-269.

Haara, F. O., Jenssen, E. S., Fossøy, I., \& Ødegård, I. K. R. (2016). The ambiguity of pedagogical entrepreneurship-the state of the art and its challenges. Education Inquiry, 7(2), 183-210.

Hannon, P. D. (2018). On becoming and being an entrepreneurship educator: A personal reflection. Entrepreneurship \& Regional Development, 30(7-8), 698-721.

Indarti, N., Hapsari, N., Lukito-Budi, A. S., \& Virgosita, R. (2020). Quo vadis, ethnic entrepreneurship? A bibliometric analysis of ethnic entrepreneurship in growing markets. Journal of Entrepreneurship in Emerging Economies, Vol. ahead-of-print No. ahead-of-print. https://doi.org/10.1108/JEEE-04-2020-0080

Kakouris, A., \& Georgiadis, P. (2016). Analysing entrepreneurship education: A bibliometric survey pattern. Journal of Global Entrepreneurship Research, 6(6), 1-18.

Krueger, N. F., Reilly, M. D., \& Carsrud, A. L. (2000). Competing models of entrepreneurial intentions. Journal of Business Venturing, 15, 411-432.

Kuratko, D. F. (2005). The emergence of entrepreneurship education: Development, trends, and challenges. Entrepreneurship Theory and Practice, 29(5), 577-597.

Liñán, F. (2004). Intention-based models of entrepreneurship education. Piccolla Impresa/Small Business, 3(1), 11-35.

Maina, S. (2013). The role of entrepreneurship education on job creation among youths in Nigeria. International Letters of Social and Humanistic Sciences, 15, 87-96.

Perianes-Rodriguez, A., Waltman, L., \& Van-Eck, N. J. (2016). Constructing bibliometric networks: A comparison between full and fractional counting. Journal of Informetrics, 10(4), 1178-1195.

Peters, H. P. F., \& Van-Raan, A. F. J. (1991). Structuring scientific activities by co-author analysis. Scientometrics, 20(1), 235-255.

Preedy, S., Jones, P., Maas, G., \& Duckett, H. (2020). Examining the perceived value of extracurricular enterprise activities in relation to entrepreneurial learning processes. Journal of Small Business and Enterprise Development, 27(7), 1085-1105.

Pritchard, A. (1969). Documentation notes? Journal of Documentation, 25(4), 344-349.

QAA (2012). Enterprise and entrepreneurship education. Guidance for UK higher education providers, draft for consultation. Gloucester: The Quality Assurance Agency for Higher Education.

QAA (2018). Enterprise and entrepreneurship education: Guidance for UK higher education providers. Gloucester: The Quality Assurance Agency for Higher Education.

Rantanen, T., \& Toikko, T. (2013). Social values, societal entrepreneurship attitudes and entrepreneurial intention of young people in the Finnish welfare state. Poznan University of Economics Review, 13(1), 7-24.

Rey-Martí, A., Ribeiro-Soriano, D., \& Palacios-Marqués, D. (2016). A bibliometric analysis of social entrepreneurship. Journal of Business Research, 69(5), 1651-1655.

Rodriguez, S., \& Lieber, H. (2020). Relationship between entrepreneurship education, entrepreneurial mindset, and career readiness in secondary students. Journal of Experiential Education, 43(3), 277-298.

Sassetti, S., Marzi, G., Cavaliere, V., \& Ciappei, C. (2018). Entrepreneurial cognition and socially situated approach: A systematic and bibliometric analysis. Scientometrics, $116,1675-1718$.

Schmitz, A., Urbano, D., Dandolini, G. A., De-Souza, J.A., \& Guerrero, M. (2017). Innovation and entrepreneurship in the academic setting: A systematic literature review. International Entrepreneurship and Management Journal, 13, 369-395. 
Servantie, V., Cabrol, M., Guieu, G., \& Boissin, J. P. (2016). Is international entrepreneurship a field? A bibliometric analysis of the literature (1989-2015). Journal of International Entrepreneurship, 14, 168-212.

Small, H. (1973). Co-citation in the scientific literature: A new measure of the relationship between two documents. Journal of the American Society for information Science, 24(4), 265-269.

Sommarström, K., Oikkonen, E., \& Pihkala, T. (2020). Entrepreneurship educationparadoxes in school-company interaction. Education+ Training, 62(7/8), 933-945.

Souitaris, V., Zerbinati, S., \& Al-Laham, A. (2007). Do entrepreneurship programmes raise entrepreneurial intention of science and engineering students? The effect of learning, inspiration and resources. Journal of Business Venturing, 22(4), 566-591.

Uribe-Toril, J., Ruiz-Real, J.L., Ceresia, F., \& Valenciano, J. D. P. (2019). Corruption and entrepreneurship: A bibliometric analysis. Journal of Legal. Ethical and Regulatory Issues, 22(4), 1-11.

Van-Eck, N. J., \& Waltman, L. (2010). Software survey: VOSviewer, a computer program forbibliometric mapping. Scientometrics, 84, 523-538.

Van-Leeuwen, T. (2004). Descriptive versus evaluative bibliometrics In Moed, H. F. Glänzel, W. and Schmoch, U. (Eds.), Handbook of Quantitative Science and Technology Research: The Use of Publication and Patent Statistics in Studies of S\&T Systems (pp. 373-388) Dordrecht, The Netherlands: Kluwer Academic Publishers.

Wang, N., Liang, H., Jia, Y., Ge, S., Xue, Y., \& Wang, Z. (2016). Cloud computing research in the IS discipline: A citation/co-citation analysis. Decision Support Systems, 86, 3547.

Wong, S. L., Nyakuma, B.B., Wong, K. Y., Lee, C. T., Lee, T. H., \& Lee, C. H. (2020). Microplastics and nanoplastics in global food webs: A bibliometric analysis (20092019). Marine Pollution Bulletin, 158(111432), 1-15.

Yu, H., Wei, Y. M., Tang, B. J., Mi, Z., \& Pan, S. Y. (2016). Assessment on the research trend of low-carbon energy technology investment: A bibliometric analysis. Applied energy, 184, 960-970.

Zhang, J., Yu, Q., Zheng, F., Long, C., Lu, Z., \& Duan, Z. (2016). Comparing keywords plus of WOS and author keywords: A case study of patient adherence research. Journal of the Association for Information Science and Technology, 67(4), 967-972.

Zheng, Y. (2018). The past, present and future of research on Chinese entrepreneurship education: A bibliometric analysis based on CSSCI journal articles. Educational Sciences: Theory \& Practice, 18(5), 1255-1276. 